Historic, archived document

Do not assume content reflects current scientific knowledge, policies, or practices. 



\section{Effect of Burning}

\section{on South Florida Range.}

$$
\text { by J.B. Hilmon \& C.E. Lewis }
$$
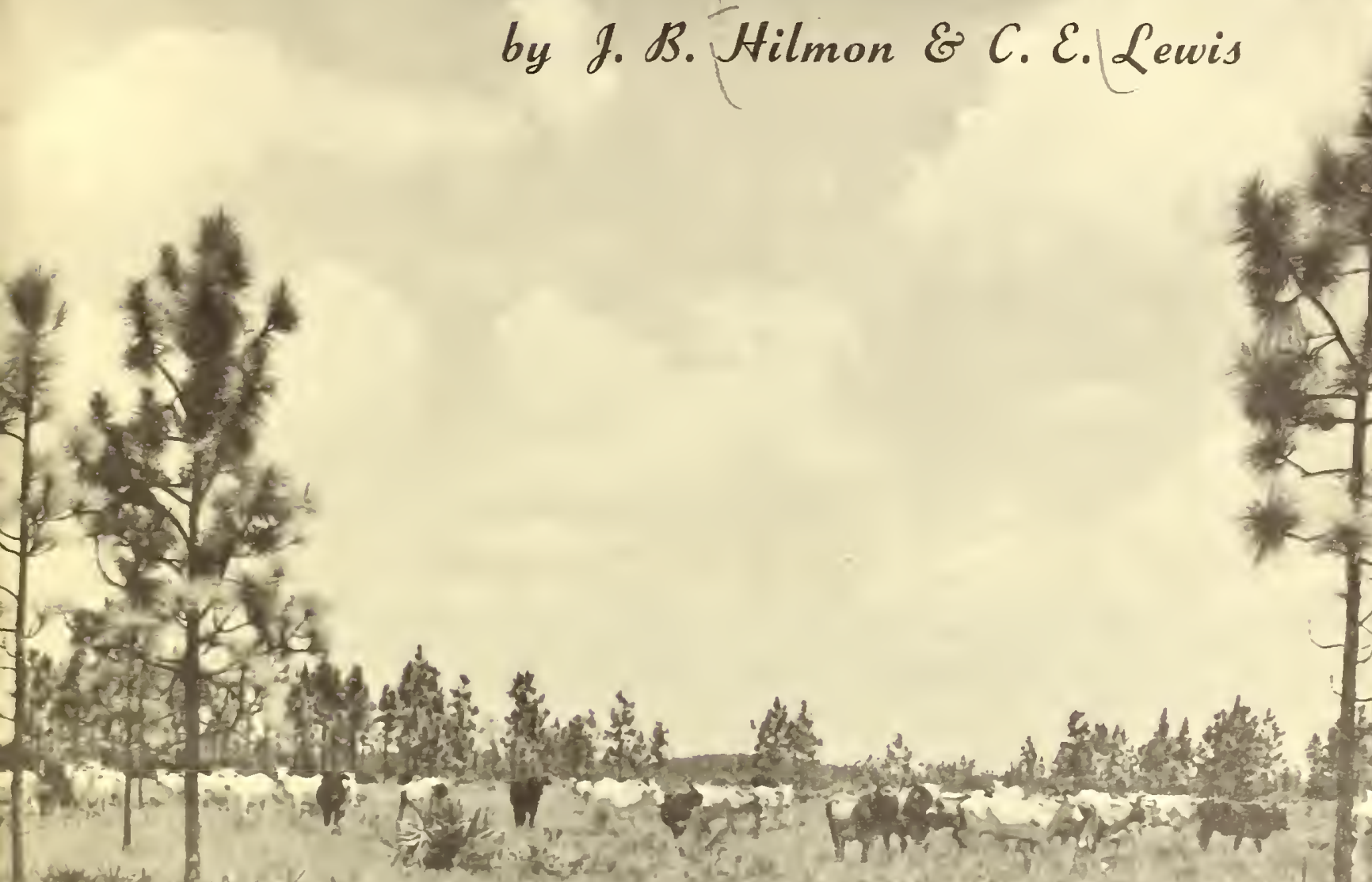

3.4.
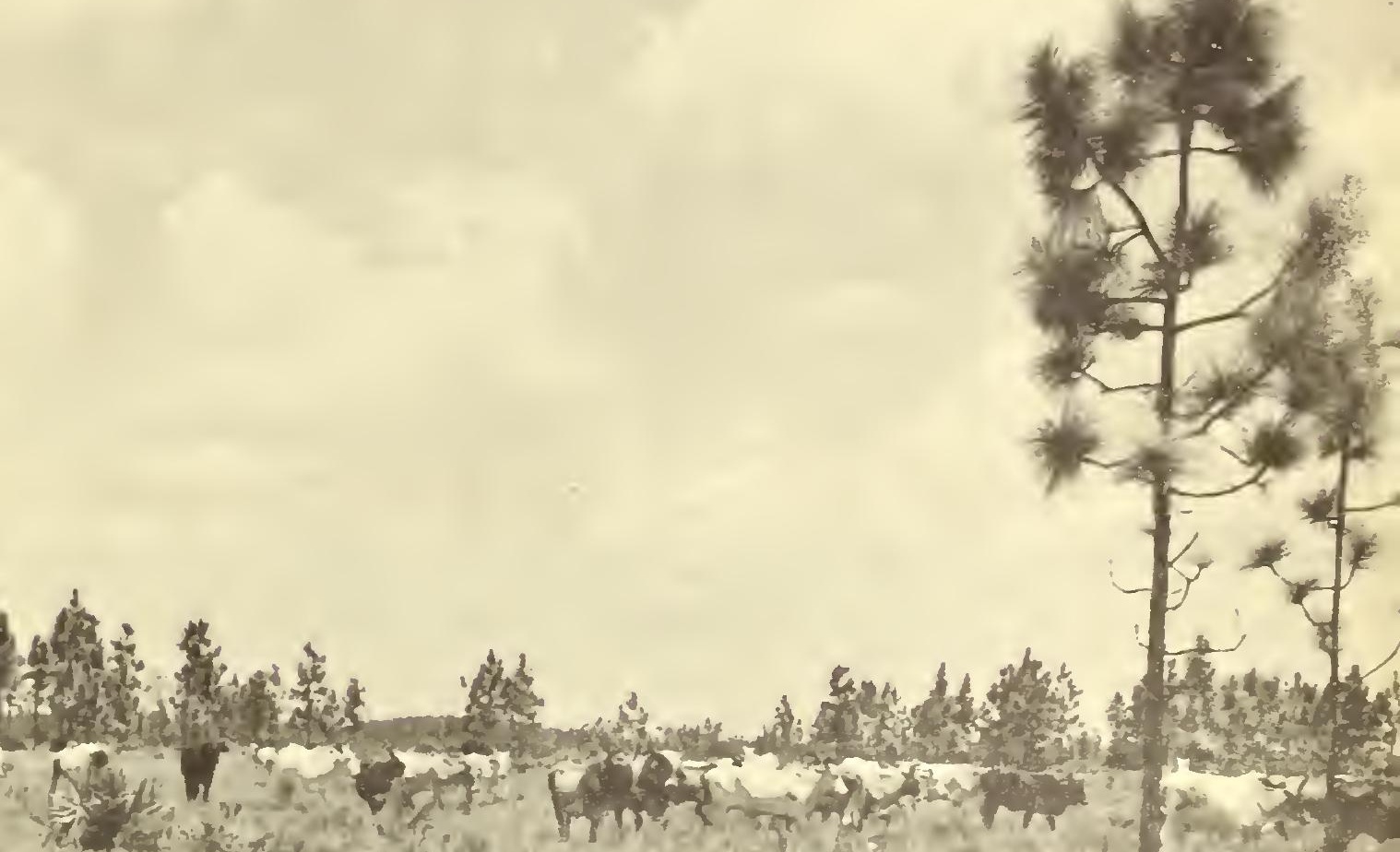

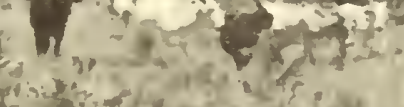

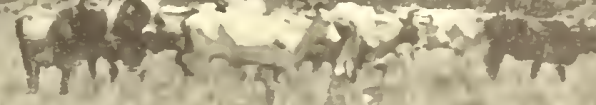

$2 y$

U.S. Department of Agriculture-Forest Service,

Station Paper, No. 146

August 1962
Southeastern Forest Experiment Station.--

-a Asheville, North Carolina 


\title{
Effect of Burning on South Florida Range
}

\author{
by J. B. Hilmon \& C. E. Lewis
}

Livestock ranges in south Florida are burned during the winter season every 2 or 3 years to remove accumulated growth and "freshen" native forage plants for cattle. This practice increases variation in herbage volume and nutritive quality, and alters seasonal patterns of herbage growth. A period of no herbage volume immediately after a fire is followed by a brief period of low herbage volume-high nutritive quality and finally, by an extended period of high herbage volume-low nutritive quality.

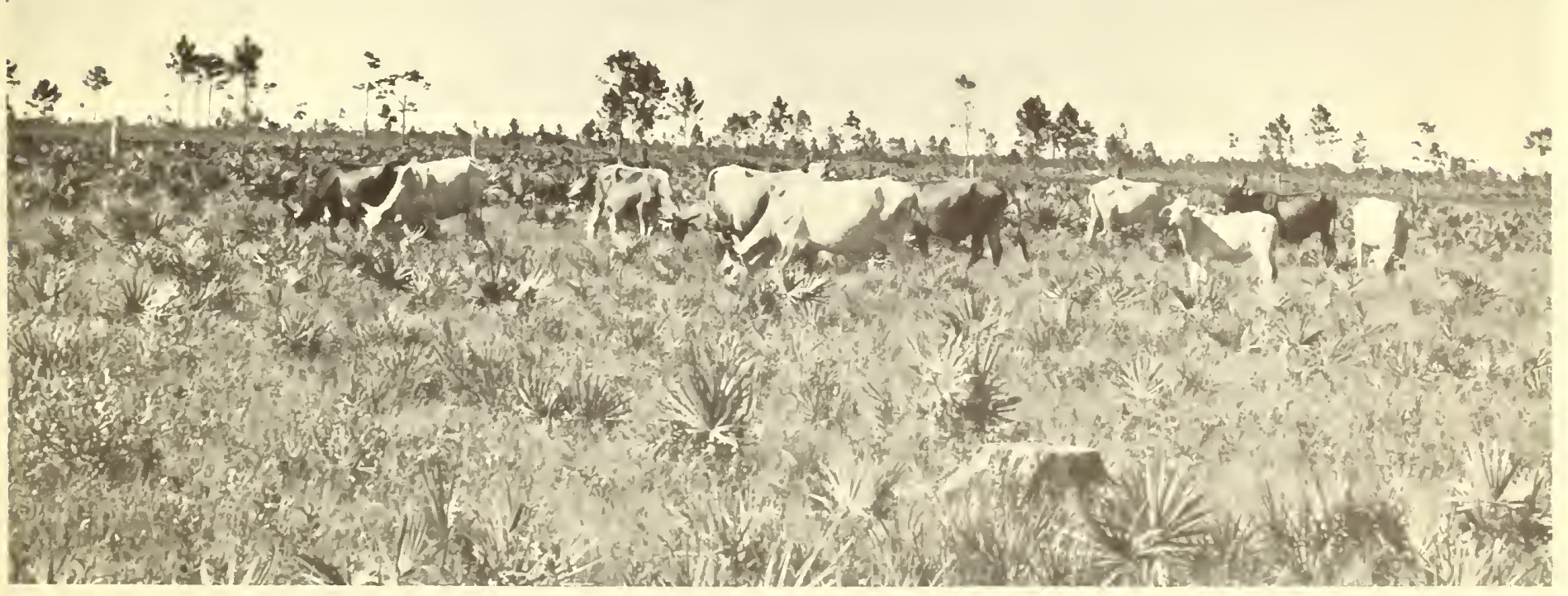

Livestock range in south Florida "freshened" for cattle. 


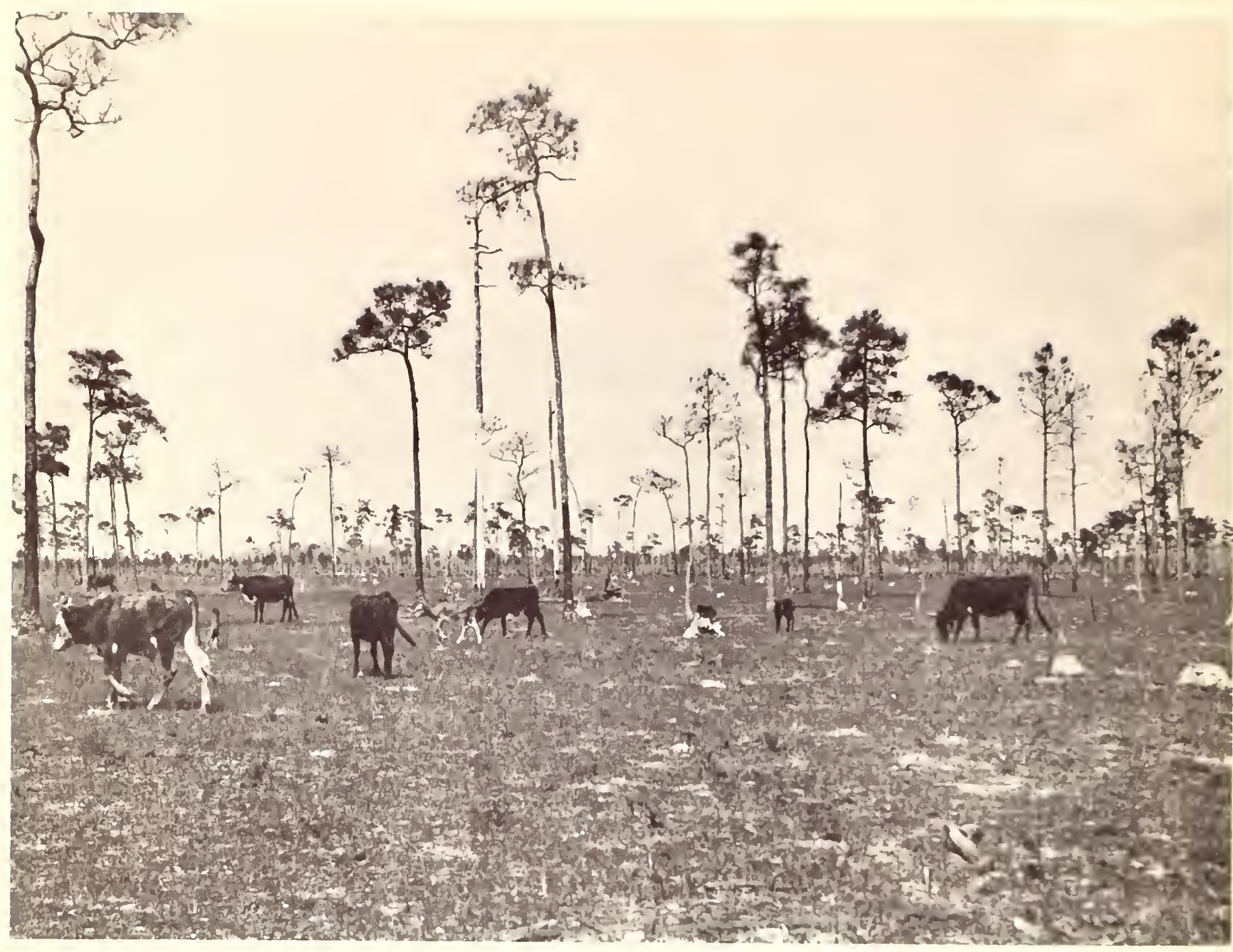

Recently burned native ranges are characterized by high quality-low volume herbage.

Davis and Kirk, I/ in tests at the Range Cattle Station, Ona, Florida, found that protein varied from 10 percent in very young wiregrass-type forage to 1.5 to 2.5 percent in old wiregrass. Phosphorus values were usually below 0.10 percent and often below 0.05 percent. Killinger $2 /$ reported as much as 0.18 phosphorus in wiregrass 211 days after burning on Leon fine sand in central Florida. Otherwise his findings were similar to those of Davis and Kirk.

The study reported here measured yield, composition, and chemical content of herbage from an ungrazed native range over a 2 -year period following a mid-February fire. The study was conducted on the Caloosa Experimental Range in Charlotte County, Florida, on lands owned by the Babcock Florida Company. Chemical analyses were made by Mr. F. E. Knox, Chemist, USDA Agricultural Research Service, Tifton, Georgia.

I/ Davis, K., and Kirk, W. G. Nutritional quality in pastures, Soil Sci. Soc. Fla. Proc. 12. 1952. 2 Killinger, G. G. Effect of burning and fertilization of wiregrass on pasture establishment. Jour, Amer. Soc. Agron. 40. 1948. 


\section{Methods}

A 1-acre plot of cutover pine flatwoods occupied by pineland three-awn (Aristida stricta) and other wiregrass-type vegetation was burned February 14 , 1957. The soil was Adamsville fine sand, a moderately wet, deep sand of low organic content and natural fertility. Beginning three weeks after the fire, herbage was sampled as shown in table 1. Some unscheduled collections for chemical analyses were made for important forage grasses.

Table 1. --Schedule of vegetation sampling for a 2 -year period after burning

\begin{tabular}{c|c|c|c}
\hline \multirow{2}{*}{ Component } & \multicolumn{3}{|c}{ Sampling interval } \\
\cline { 2 - 3 } & $\begin{array}{c}3-7-57 \\
\text { to }\end{array}$ & $\begin{array}{c}7-11-57 \\
\text { to }\end{array}$ & $\begin{array}{c}2-11-58 \\
\text { to }\end{array}$ \\
$7-11-57$ & $2-11-58$ & $2-10-59$ \\
\hline
\end{tabular}

\begin{tabular}{lccc} 
Total understory & 14 & -- & -- \\
$\begin{array}{lccc}\text { Aristida stricta } \\
\begin{array}{c}\text { Other herbaceous } \\
\text { understory }\end{array}\end{array}$ & $\underline{1} /)$ & $\underline{2} / 30$ & 90 \\
Shrubs & $(\underline{1} /)$ & 30 & 90 \\
\hline
\end{tabular}
content.

1/ This component not sampled for chemical

2/ Chemical content analyzed only at 90-day intervals.

joint between leaf and petiole. Beginning in December of the first year, dead material was gleaned from plots prior to clipping. Plant material was ovendried and analyzed for crude protein, ash, ether extract, cellulose, lignin, other carbohydrates (by difference), calcium, and phosphorus. Methods of analysis were those reported by Halls et al. 3 /

\section{Yield and Species Composition}

Total herbage increased from 66 pounds (moisture free) per acre 3 weeks after burning to a maximum of 3,568 pounds in the fall of the second year (fig. 1). Maximum herbage produced the first year following burning was 2,224 pounds per acre harvested in the late fall. Herbage production declined after November each year.

Pineland three-awn was the first species to recover and was the principal contributor to herbaceous composition throughout the 2-year period of study. This one species comprised 97 percent of the total herbage 3 weeks after burning, 90 percent after 5 weeks, and 73 to 83 percent thereafter (table 2).

3/ Halls, L. K., Hale, O. M., and Knox, F. E. Seasonal variation in grazing use, nutritive content and digestibility of wiregrass forage. Ga. Agr. Expt. Sta. Tech. Bul. (n. s.) 11. 1957. 


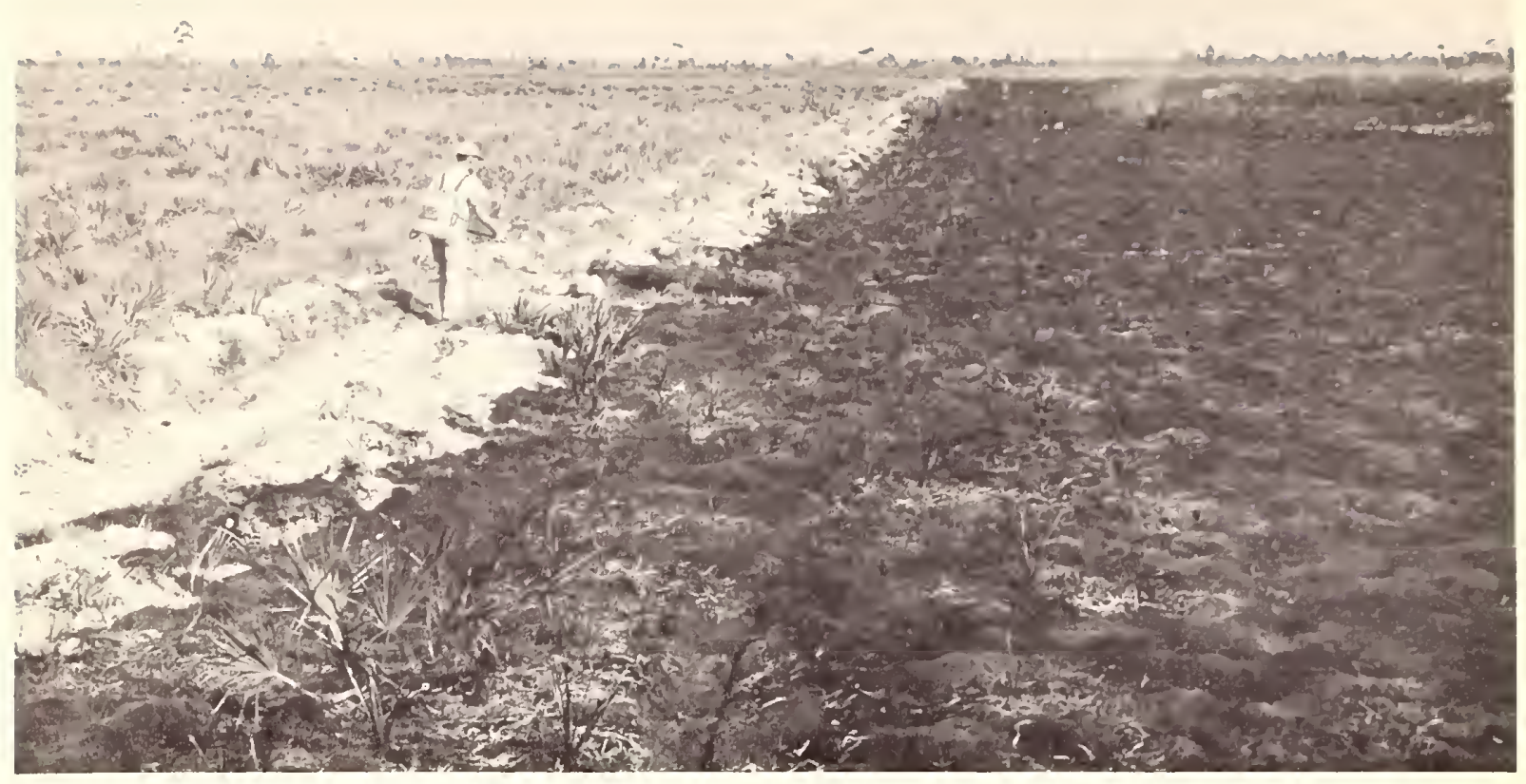

Burning on the Caloosa Experimental Range for herbage production study.

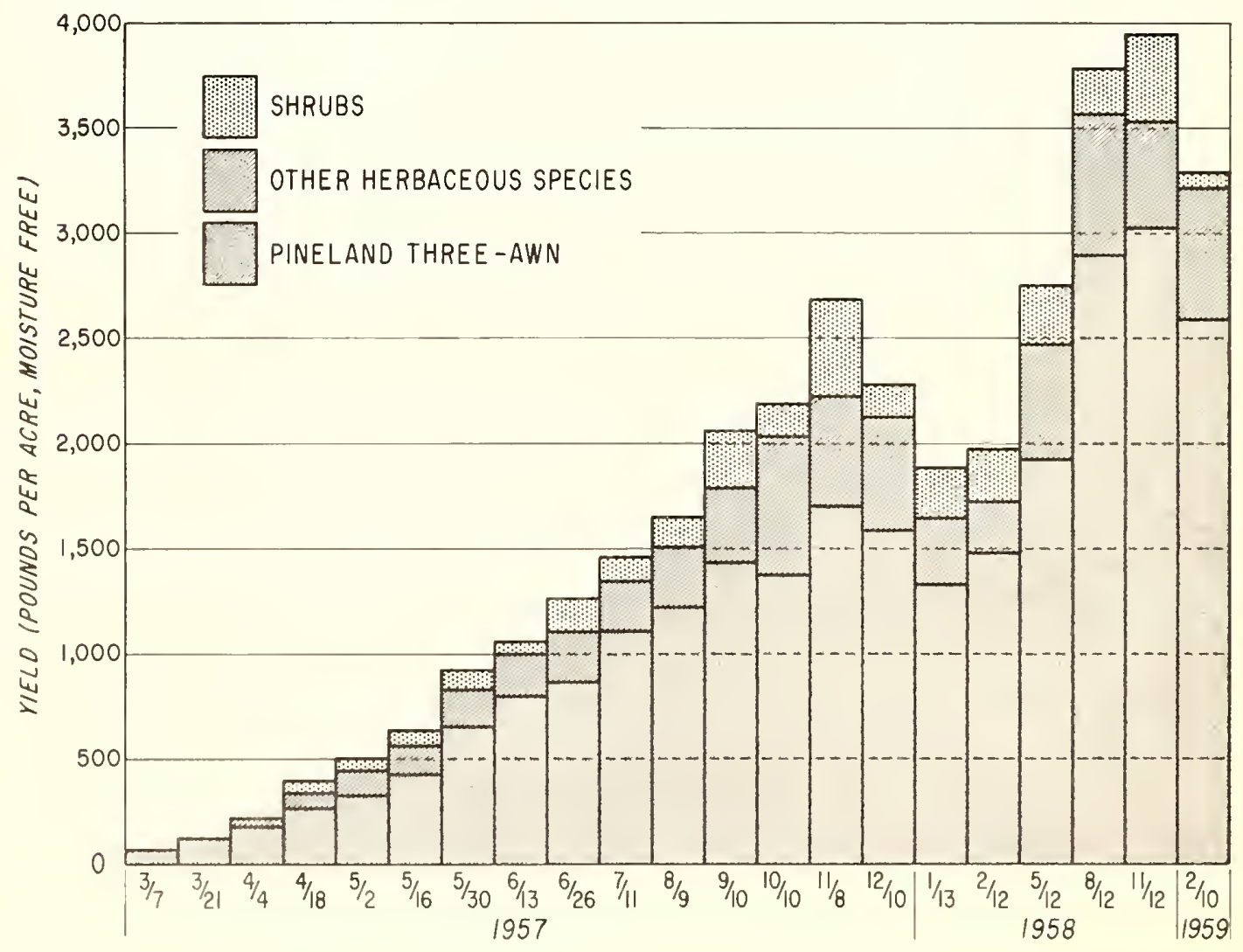

Figure 1.--Yield of pineland three-awn, other herbaceous species, and shrubs on a south Florida range over a 2 -year period following a February 14, 1957, fire. 
Pineland three-awn, the principal plant in the herbaceous understory on most pine flatwoods ranges in south Florida.

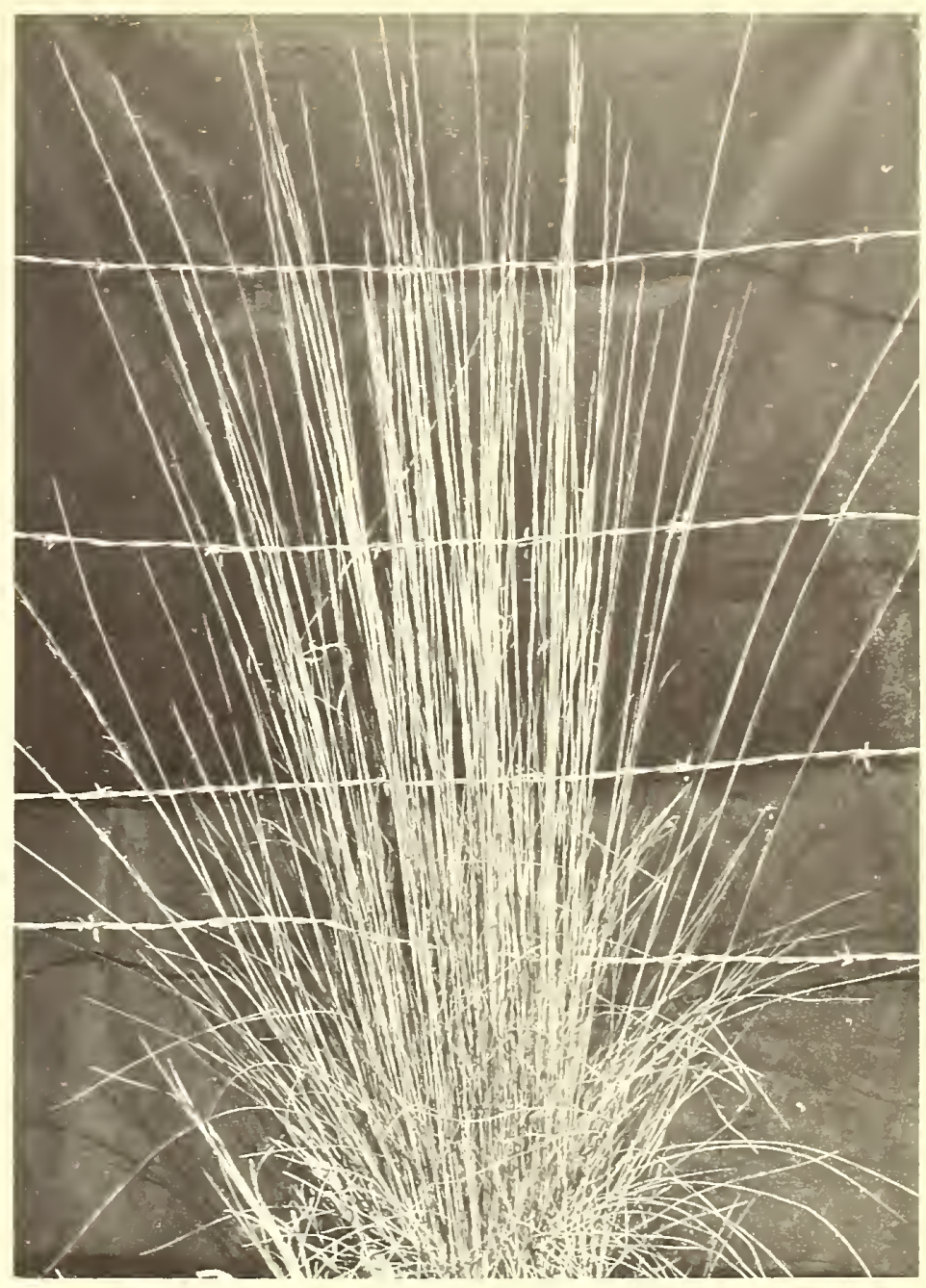

Table 2. --Major components of understory herbage on a south Florida range over a 2 -year period following a fire on February 14, 1957

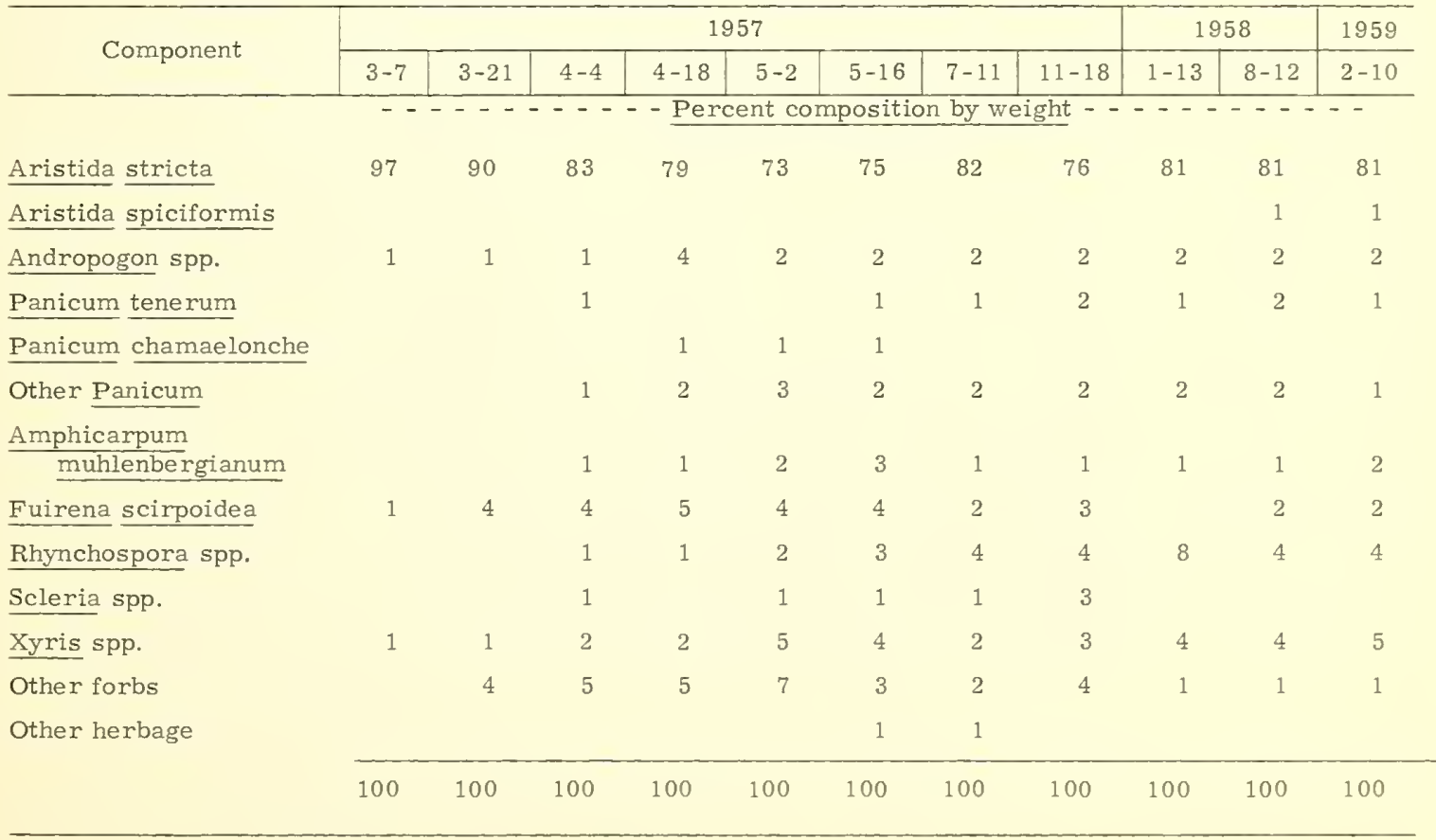


Four or five other species, including yellowsedge bluestem (Andropogon virginicus), chalky bluestem (Andropogon capillipes), umbrella grass (Fuirena scirpoidea) and yelloweyed grass (Xyris elliottii), had begun growth 3 weeks after the fire, but these species contributed only 3 percent of total herbage production. From 5 to 11 weeks after the range was burned, a variety of forbs dominated the "other understory." Forbs (other than species of Xyris) then declined and became relatively unimportant.

Six or seven grasses, all palatable to cattle, contributed significantly to the "other understory": goobergrass (Amphicarpum muhlenbergianum), yellowsedge bluestem, chalky bluestem, and three or four panics, including primarily Panicum tenerum and Panicum chamaelonche.

Only one palatable grasslike plant, umbrella grass, contributed materially to the understory. Other grasslikes, predominantly beakrushes (Rhynchospora spp.) and razorsedges (Scleria spp.), increased consistently over the 2-year period. Scleria ciliata increased markedly in the fall of the first year. This plant is grazed by cattle and its seeds are eaten by quail.

Shrub cover was sparse on the study area, and considerable variability in volume was encountered in sampling. Shrubs reached a maximum of slightly over 400 pounds per acre toward the end of the second year. Sawpalmetto and seminoletea pawpaw (Asimina reticulata) were the first shrubs to resprout in measurable amounts; measurable volumes were recorded April 4, seven weeks after burning the range. Saw-palmetto, which comprised 90 percent or more of the shrub volume, was widespread on the study area. Two other shrubs, gallberry (Ilex glabra) and gopherapple (Chrysobalanus oblongifolius), were encountered sparingly.

As pineland three-awn and other wiregrasses mature, yellowsedge bluestem (foreground) assumes a greater part of the grazing load.

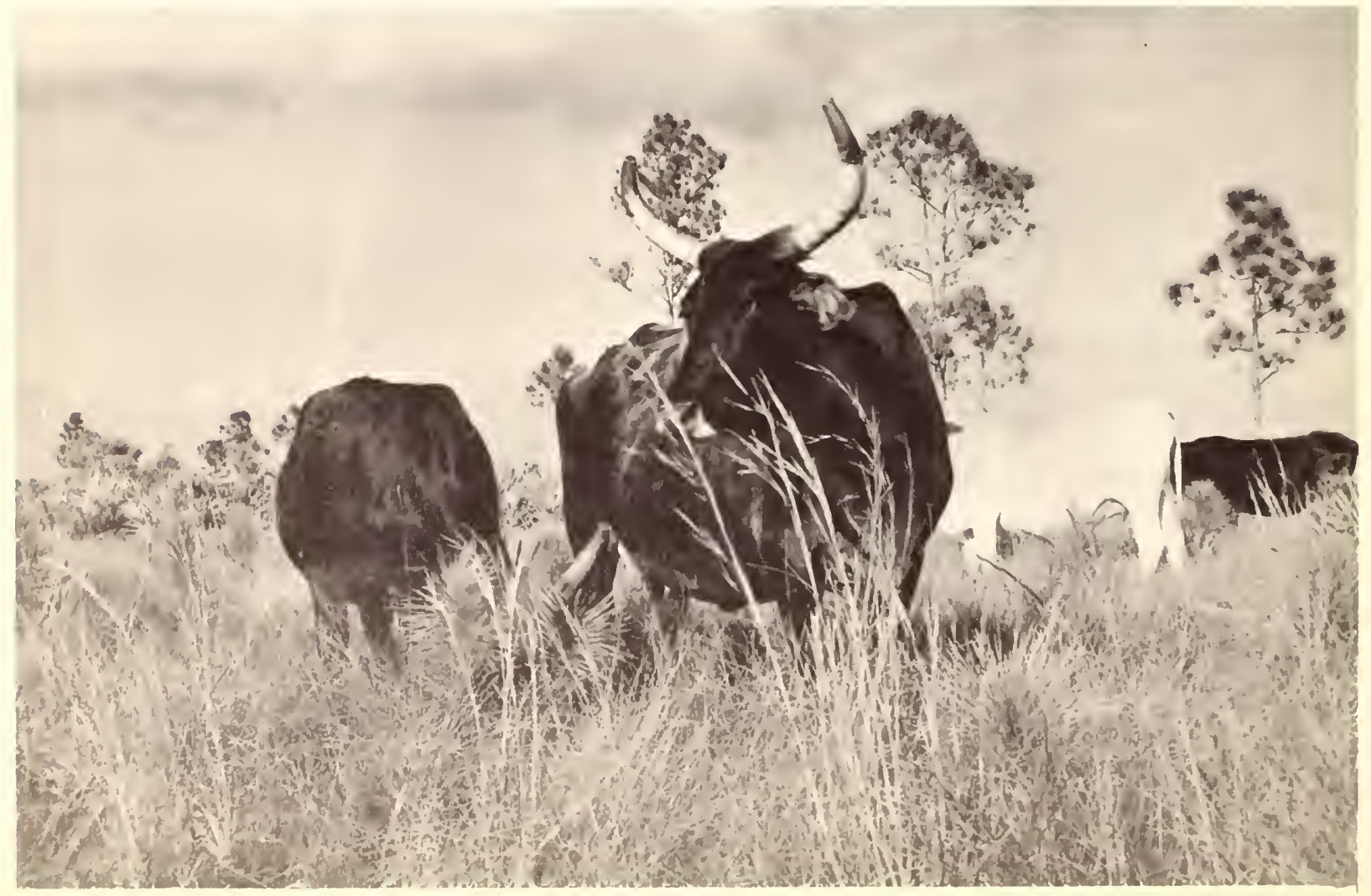


Trends in chemical content generally followed those reported by Davis and Kirk (see footnote 1). Younger herbage emerging after the fire was higher in protein, ash, calcium, and phosphorus, and lower in lignin than more mature herbage (tables 3 and 4). Trends were most noticeable during the first 5 months (fig. 2).

Table 3. --Chemical composition of herbage in the understory vegetation for 2 years after burning on February 14, 1957

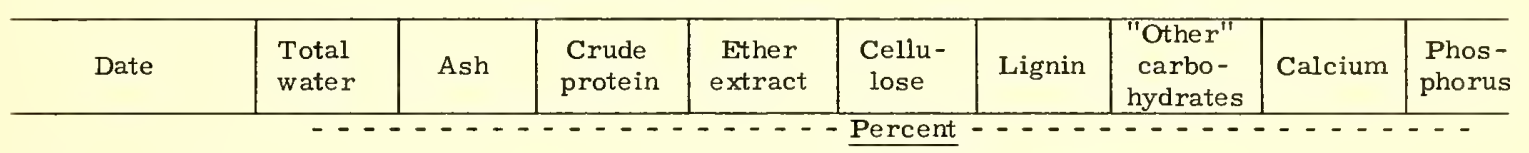

Total understory

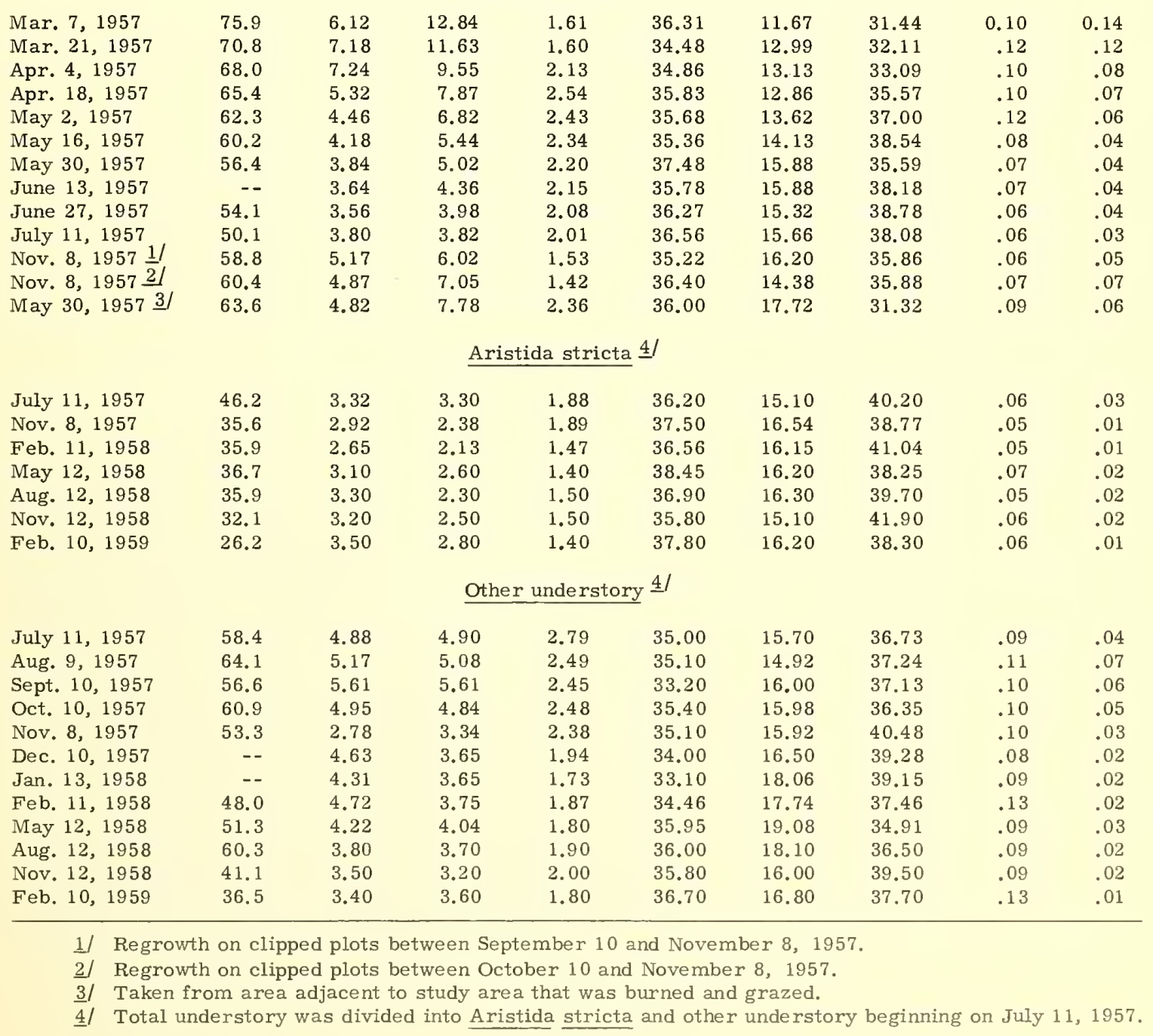


Table 4. - Chemical eomposition of shrubs for 2 years after burning on February 14, 1957

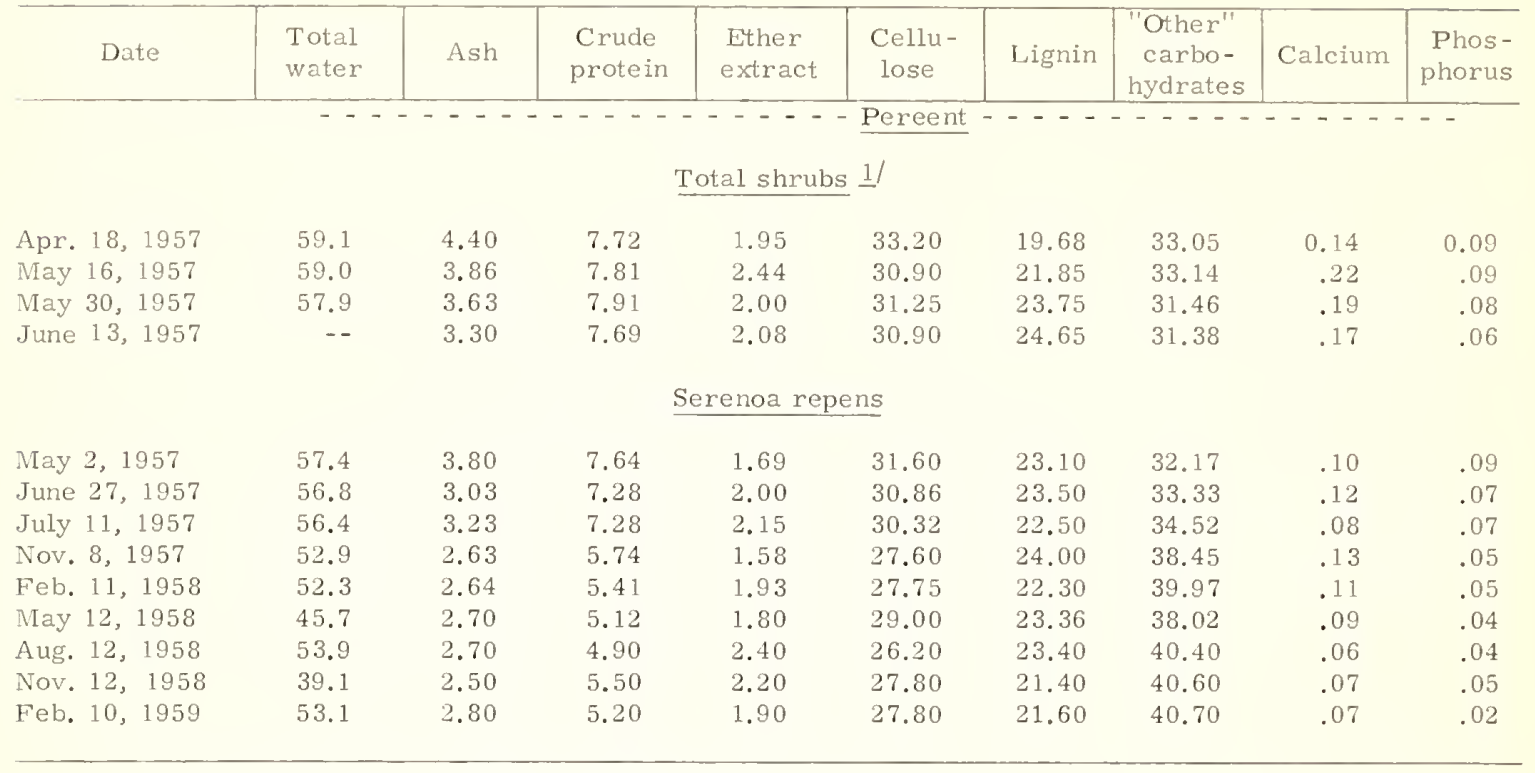

1/ Composed primarily of Serenoa repens.

Crude protein content was highest in the new growth of all vegetation, but decreased as the plants matured. Total understory, primarily pineland three-awn, decreased rapidly from 12.84 percent to 3.82 percent crude protein during the 5 months following fire. Other understory increased in crude protein content from July 11 to September 10,1957. Thereafter, other understory followed the gradual downward trend of pineland three-awn to more or less uniformly low levels. After April 18, shrubs were higher in crude protein than understory herbage.

Young sprouts of understory herbage contained 0.14 percent phosphorus. Content decreased rapidly from this peak to 0.04 percent 3 months after the fire, and remained near or below this low level throughout the 2-year period. Similar trends and levels were found for saw-palmetto. On the 2-year rough none of the groups or species sampled contained more than 0.02 percent phosphorus.

Calcium content of understory herbage fluctuated from 0.10 to 0.12 percent during the 3 -month period following burning, declined gradually during the next two months to a level of 0.06 percent, and held at about this low level throughout the next 18 months. Other understory herbage contained higher percentages of calcium than pineland three-awn throughout most of the 2-year period. This component of the vegetation was highest in percent calcium (0.13) in February, both in 1958 and 1959. New growth of shrubs was very high in calcium. Content in saw-palmetto, the principal shrub, decreased during the second year to about the same low level found for pineland three-awn. 


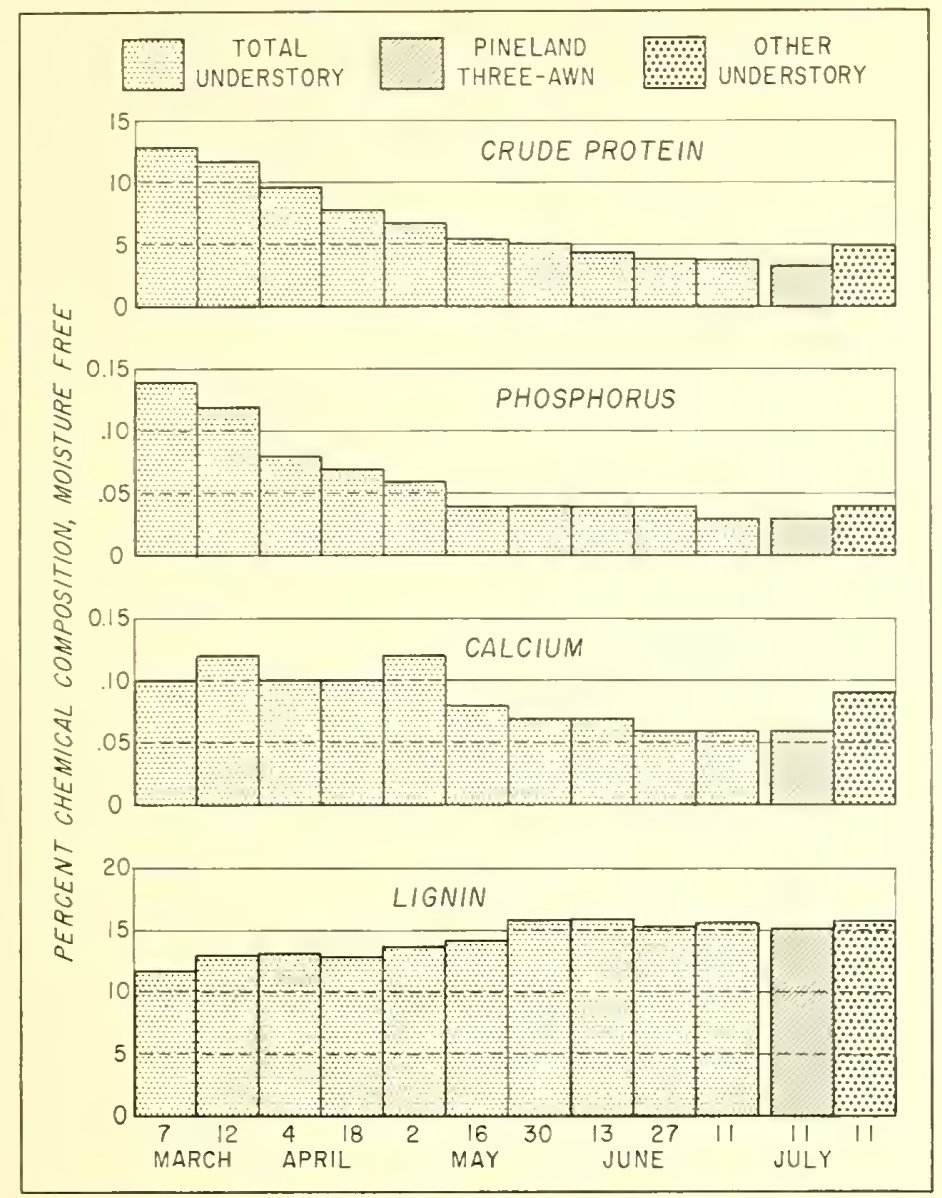

Figure 2.--Percent chemical composition of herbage for 5 months after burning on February 14, 1957.

Lignin for the most part increased rapidly during the first 3 months of vegetative growth. After the initial increase, lignin content remained fairly constant.

The lower portions of buds, or emerging leaves, of saw-palmetto were higher in crude protein and phosphorus, while lower in lignin than the mature fronds (tables 4 and 5). Chalky bluestem, lopside Indiangrass (Sorghastrum secundum), and goobergrass were generally higher in calcium and phosphorus and lower in lignin than total understory. Goobergrass was considerably higher in ash, crude protein, calcium, and phosphorus, while lower in lignin than total understory on the dates the additional species were sampled.

Leaves of saw-palmettoes growing on a nearby Keri fine sand with underlying marl contained 0.29 percent calcium (table 5). Palmettoes in this area had been grazed heavily by cattle. No notable differences between upper and lower portions of saw-palmetto leaves were found on this site.

Seasonal trends in chemical content of herbage growing on the experimental area were not conspicuous. Other carbohydrates in other understory herbage were slightly higher than average in the fall and slightly lower than average in the late spring. 
Table 5.--Chemical composition of supplemental samples of grasses and individual portions of saw-palmetto

\begin{tabular}{|c|c|c|c|c|c|c|c|c|c|}
\hline Date & $\begin{array}{l}\text { Total } \\
\text { water }\end{array}$ & Ash & $\begin{array}{l}\text { Crude } \\
\text { protein }\end{array}$ & $\begin{array}{l}\text { Ether } \\
\text { extract }\end{array}$ & $\begin{array}{l}\text { Cellu - } \\
\text { lose }\end{array}$ & Lignin & $\begin{array}{l}\text { "Other" } \\
\text { carbo- } \\
\text { hydrates }\end{array}$ & Calcium & $\begin{array}{l}\text { Phos - } \\
\text { phorus }\end{array}$ \\
\hline \multicolumn{10}{|c|}{ Andropogon capillipes } \\
\hline \multicolumn{9}{|c|}{ Amphicarpum muhlenbergianum } & 0.06 \\
\hline Apr. 18, 1957 & 72.1 & 10.25 & 11.70 & 3.71 & 29.70 & 7.03 & 37.61 & .14 & .08 \\
\hline \multicolumn{10}{|c|}{$\underline{\text { Sorghastrum secundum }}$} \\
\hline \multicolumn{9}{|c|}{ Serenoa repens } & .07 \\
\hline $\begin{array}{l}\text { Feb. } 12,1958 \frac{1}{2} / \\
\text { Feb. } 12,1958 \underline{2} / \\
\text { Feb. } 11,1959 \underline{3} / \\
\text { Feb. 11, } 1959 \underline{4} /\end{array}$ & $\begin{array}{r}59.1 \\
74.2 \\
-- \\
--\end{array}$ & $\begin{array}{l}3.60 \\
4.68 \\
3.50 \\
3.30\end{array}$ & $\begin{array}{l}5.36 \\
7.57 \\
7.30 \\
6.70\end{array}$ & $\begin{array}{l}1.85 \\
1.69 \\
1.90 \\
1.60\end{array}$ & $\begin{array}{l}31.90 \\
34.10 \\
24.10 \\
26.50\end{array}$ & $\begin{array}{l}22.72 \\
18.00 \\
25.10 \\
24.40\end{array}$ & $\begin{array}{l}34.57 \\
35.96 \\
38.10 \\
37.50\end{array}$ & $\begin{array}{l}.13 \\
.11 \\
.29 \\
.29\end{array}$ & $\begin{array}{l}.09 \\
.13 \\
.05 \\
.05\end{array}$ \\
\hline
\end{tabular}

1/ Upper portion of buds on the study area.

2/ Lower portion of buds on the study area.

3/ Upper portion of fronds on Keri fine sand underlain by marl.

4/ Lower portion of fronds on Keri fine sand underlain by marl.

\section{Discussion}

Herbage on south Florida ranges emerged rapidly after burning in February. Growth during the first 3 weeks was 66 pounds per acre, or an average of 3.1 pounds per acre per day. This increased to 19.0 pounds per acre per day for the 2 -week period ending May 30, 1957. Thereafter, growth slowed to average about 4 pounds per acre per day over the 2 -year period.

While occasional subnormal weather in the winter or inundation of vegetation during the summer greatly curtailed plant growth, some growth continued most of the year. Beginning in late November and continuing until mid-January, herbage deterioration exceeded growth, and the total volume of herbage declined. December 1957 was abnormally cold; for example, the temperature dropped to $27^{\circ} \mathrm{F}$. on December 12 and $13,1957$.

Pineland three-awn, through its ability to resprout rapidly after burning, maintains dominance in the understory on south Florida ranges. During the first 2 or 3 months on recent burns, this species is the primary component of cattle diet. As pineland three-awn matures, a greater proportion of the other plants are consumed.

Although herbage yield was low on recent burns, nutritive quality was higher than any other time during the 2 years. Nine to 11 weeks following the fire, crude protein had decreased to inadequate levels for cattle maintenance (National Research Council 4 ).

4' National Research Council. Nutrient requirements of domestic animals. No. 4: Nutrient requirements of beef cattle. Natl. Acad. Sci. Pub. 579. 1958. 
Chemical analyses of herbage from adjacent grazed range indicated that grazing may delay a rapid drop in protein. The level of protein in grazed herbage collected on May 30,1957, was about the same as in ungrazed herbage collected six weeks earlier (table 2).

Phosphorus--borderline for proper animal nutrition 3 weeks after burning--was deficient in all subsequent samplings. In no case did calcium meet minimum requirements for cattle maintenance. Most ranchers feed mineral supplements high in phosphorus and calcium year-round to cattle on native range.

Shrubs, especially saw-palmetto, are more abundant on many south Florida ranges than data from this study would indicate. Leaves of sawpalmetto emerging on recently burned ranges are grazed by cattle, and mature fronds are occasionally cropped heavily when a sufficient variety or volume of forage is not available. Unfolding leaves were higher in crude protein and phosphorus, but lower in lignin, than mature fronds. Although shrubs generally contained more crude protein, calcium, and phosphorus than understory vegetation, their lignin content was also higher. Consequently, the nutrients in saw-palmetto and other woody growth were probably less available. On some sites where marl is near the soil surface, cattle may heavily graze palmettoes because of the higher-than-average calcium content.

Heavy grazing (foreground) delays the rapid drop in protein in recently burned herbage.

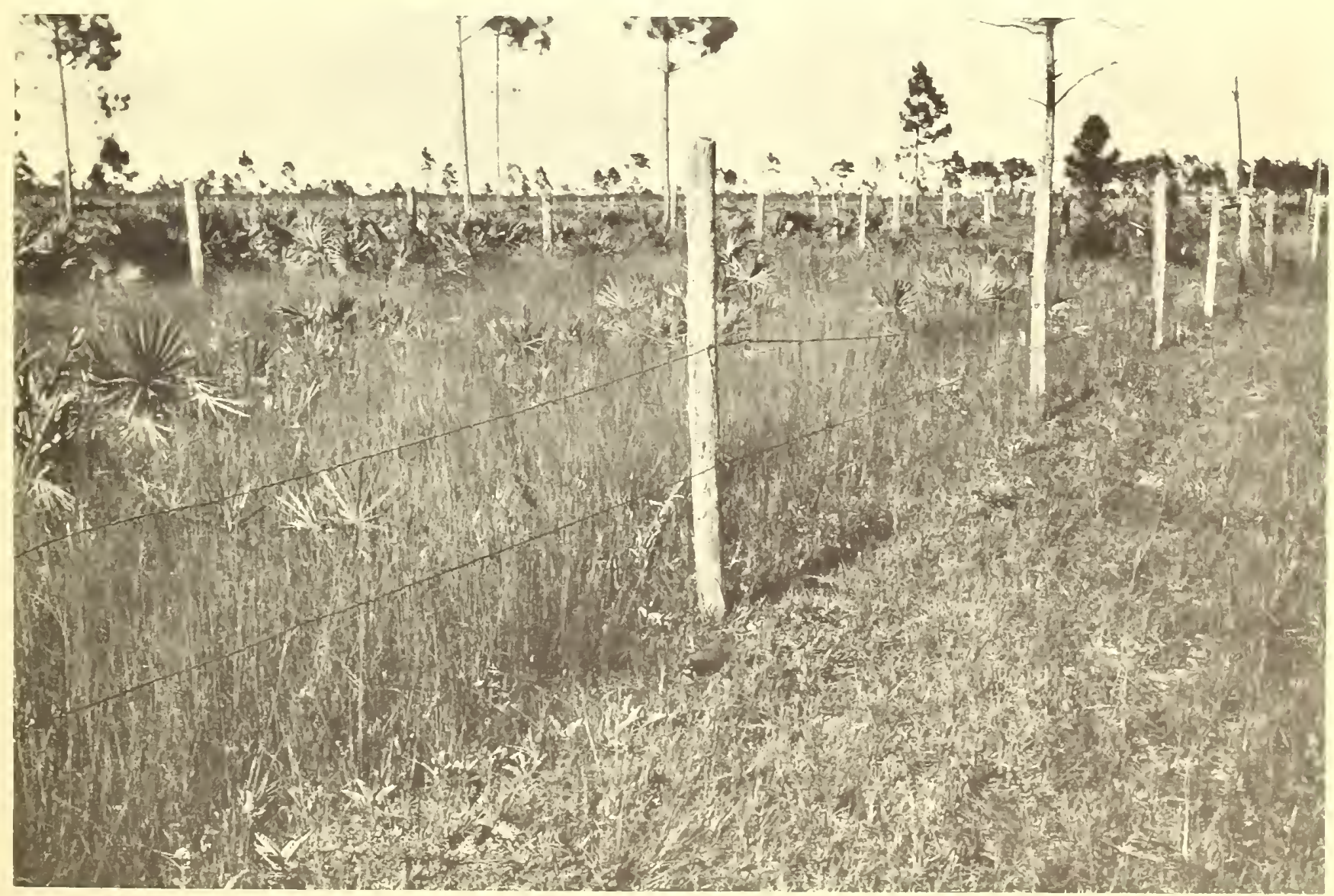




\section{$\underline{\text { Summary }}$}

Livestock ranges in south Florida are burned during the winter season every 2 or 3 years to remove old growth and provide cattle with readily available new growth. A study on the Caloosa Experimental Range, Charlotte County, Florida, measured yield, composition, and chemical content of herbage from ungrazed native range during a 2-year period following burning on February 14, 1957.

Production of herbage increased rapidly following burning. Yields were 66 pounds per acre at 3 weeks and 2,200 pounds per acre at 9 months. The highest accumulative production, approximately 3,500 pounds per acre, was attained in November of the second year. Shrubs were relatively unimportant on the study area.

Pineland three-awn was the principal plant in the herbaceous understory. It comprised 95 percent of the total herbage 3 weeks after burning and thereafter averaged 75 to 80 percent. A variety of other grasses, grasslikes, and forbs contributed to total herbage. Saw-palmetto was the principal shrub on the study area and comprised 90 percent or more of browse volume.

Nutrient levels of herbage were generally highest in the young growth immediately after burning. Crude protein in pineland three-awn and other herbage decreased rapidly to amounts inadequate for cattle; calcium and phosphorus were always inadequate. Mineral supplement affords an effective means of offsetting nutrient decline and enables ranchers to make use of the large volumes of feed produced on native ranges. Other management tools for maintaining or improving forage quality--such as progressive burning over the winter season and additions of low-cost rock phosphate--merit further research attention. 

